\title{
FORMATION OF THE COST OF RESIDENTIAL OBJECTS IN NEW BUILDINGS
}

\section{Daria Davydenko ${ }^{1}$}

\section{DOI: https://doi.org/10.30525/978-9934-588-39-6-46}

Order of the State Property Fund of Ukraine, the Ministry of Regional Development, Construction and Housing and Communal Services of Ukraine № 3379/430 of 27.08.2012, registered by the Ministry of Justice of Ukraine № 1608/21920 of 19.09.2012 [1] the Procedure for determining the cost of reconstruction or replacement of land improvements - houses, buildings and structures of multi-storey residential construction, which regulates the process of determining the value of a residential object in new buildings, has been put into effect. There is no separate normative act regulating the formation of the value of the newly built object without amendment for reproduction or replacement in Ukraine, but certain standards of the Ministry of Housing and Communal Services of Ukraine undoubtedly emphasize these aspects.

According to this Procedure, the indicators of determining the cost of a residential object are reduced to the estimation of the construction and installation costs of the developer, its administrative costs, estimated profit, value added tax, costs for preparing the territory for construction, creation of engineering networks, structures and funds to cover the risk of all construction participants. Of course, the value of a residential property has formed depending on the cost of building materials. And, a brick house costs more than a monolithic slab house. Most of the costs presented are logical in view of the construction process, but it is unclear to the individual planning to purchase a home the formation of the estimated profit and the amount of funds to cover the risk of participants.

There is no single point of view on the mechanism for generating profit for the builder. Some scientists [2, p. 23-31] consider that this concept implies additional costs for the construction of the object, the expectations of the developer to return the invested funds in view of changes in their value over time, the expectations of the developer to obtain a minimum defined profit as compensation for the risks of investing in this volume. real estate. Therefore, in their opinion, the size of such a profit and its structure - an individual vision of the developer of their own expectations.

\footnotetext{
${ }^{1}$ Kharkiv Research Institute of Forensic Examinations of the Ministry of Justice of Ukraine, Ukraine
} 
In view of this, the final value of a particular dwelling object must be constant and logically justified. But, in practice, there is a tendency to change the value of a particular housing object, which is not justified. Yes, there is a certain question of the availability of the necessary model of the behavior of the developer when forming the value of a residential object in a no-build for the end buyer.

Over the last decade, the market for construction of new buildings has expanded significantly and it is quite normal for clients to have a situation in which the cost of an apartment at the stage of the «pit» is $20 \%$ less than the value of the object in the completed housing, which is confirmed by studies of modern scientists [3] and market trends in general [4]. Looking at the history of changes in the cost of apartments in new buildings in Ukraine, for example, in the city of Kharkiv, one can trace some dynamics to an increase, depending on the change in the stage of construction. Moreover, it is absolutely irrelevant who is the developer - the trend in relative expression is the same. Such changes are an expression of the cost to cover the risk of the developer the more completed construction of the object, the lower the risk of unfinished for clients.

All these processes are deeply embedded in the cost of the apartment and rarely bother the buyer. When choosing a residential property, the buyer works closely with either the sales department of the developer or the real estate agencies that target their clients to consider the value of the individual apartment in terms of its area, planning, construction stage, floor, area, infrastructure, construction technology, availability and type of processing, reputation of the developer.

Such a list of criteria for the formation of the cost of the apartment is more attractive to customers who are planning to buy a home. But it is worth noting that not all of them are important for the valuation of a residential property. For you value of the more important components it is suggested to construct a regression model. Matrix indicators (for relative criteria) and value values (for absolute criteria) became the initial data for model construction. All data for the standard regression model algorithm are standardized and adjusted. Obtained by preliminary calculations (by Kramer method), determinants allow us to form the following regression model:

$$
Y=13,47-3,34 x_{1}+0,05 x_{2}+0,05 x_{3}+4,29 x_{4}+7,6 x_{5},
$$

where $x_{1}$ - reputation of the developer;

$x_{2}$ - object class;

$x_{3}$ - dwelling place $\left(\mathrm{m}^{2}\right)$;

$x_{4}$ - planning of the real estate object;

$x_{5}$ - location area. 
As can be seen from the presented model, variables that affect the value of an investment object, reduce it $\left(\mathrm{x}_{1}\right)$ or increase $\left(\mathrm{x}_{3}, \mathrm{x}_{4}, \mathrm{x}_{5}\right)$. It is also noted that the coefficients obtained are not similar in value, and therefore, they all affect the resulting trait equally. To determine the effectiveness of this model, its adequacy has been tested. Changes in each indicator by $1 \%$ affect the change in the resultant factor, thus forming the value of the residential property. The results of calculations of the influence of the constituent variables on the resultant factor, ie the cost of residential lack of homogeneity, are given in table 1 .

Table 1

\section{Calculation of the level of influence of components on the value of the object in the new building}

The level of influence of the components $\left(\mathrm{x}_{\mathbf{1}}-\mathrm{x}_{\mathbf{6}}\right)$ on the resultant factor $(\mathrm{Y})$

$\mathrm{E}_{1}=13,47 \times 0,30 / 16,03=0,25(25 \%) \quad \mathrm{E}_{4}=4,29 \times 0,44 / 16,03=0,12(12 \%)$

$\mathrm{E}_{2}=3,34 \times 0,44 / 16,03=0,09(9 \%) \quad \mathrm{E}_{5}=7,6 \times 0,67 / 16,03=0,32(32 \%)$

$\mathrm{E}_{3}=0,05 \times 42,48 / 16,03=0,13(13 \%)$

Elasticity is not part of the model quality check process, but it does reinforce the economic interpretation of regression - the change in the cost of a housing object from a change in factors. Thus, the calculations show that the value of the property in the new building will change with the increase or decrease of the index of the developer $25 \%$, the location of new buildings by $32 \%$ and the location area of $13 \%$, object class $9 \%$, type of new building $12 \%$. All the criteria presented have a significant impact on the cost of the apartment according to the presented regression model.

Thus, it can be concluded that the process of forming the value of residential objects in the new building is a dynamic process, and the list of impact criteria is not exhaustive, which allows the developer to change the cost component of the housing object at its own discretion. needed. Compulsory construction costs, as the study found, are not essential to determining the final cost of a home, enabling the building to appeal and manipulate the criteria of the object class, number of floors, planning, location, etc. All of these problematic issues can be solved out-of-the-way. In the presence of the relevant normative act in the Ukrainian legislation, to regulate the process of forming the cost of living, the developer had some restrictions on their own incentives, and the clients clearly understood the quality of their money invested in real estate. 


\section{References:}

1. Pro zatverdzhennja Porjadku vyznachennja vartosti vidtvorennja chy zamishhennja zemeljnykh polipshenj - budynkiv, budivelj ta sporud malopoverkhovogho zhyt-lovogho budivnyctva [On Approval of the Procedure for Determining the Cost of Reproduction or Replacement of Land Improvements Buildings, Buildings and Structures of Low-rise Residential Construction]. Nakaz Fondu derzhavnogho majna Ukrajiny Ministerstva reghionaljnogho rozvytku, budivnyctva Ukrajiny z zhytlovo-komunaljnogho ghos-podarstva Ukrajiny [Order of the State Property Fund of Ukraine of the Ministry of Regional Development, Construction of Ukraine on Housing and Communal Services of Ukraine] № . 1608/21920 of 19 September 2012. Retrieved from: https://zakon.rada.gov.ua/ laws/ show/z1608-12 (accessed 19 March 2020).

2. Kuznetsov, S. M., Kholomeeva, N. V., Olkhovikov, S. E. (2014). Obosnovanie riska prodolzhitel'nosti stroitel'stva obektov [Rationale for the duration of construction of facilities]. Research publications, vol. 3, no. 7, pp. 23-31. (in Russian)

3. Davydenko, D. O. (2017) Formuvannja mekhanizmu finansovykh poslugh dlja zdijsnennja operacij z zhytlovoju nerukhomistju [Formation of the mechanism of financial services for transactions with residential real estate], ( $\mathrm{PhD}$ Thesis). Kharkiv: Simon Kuznets Kharkiv National University of Economics. (in Ukrainian)

4. Oficijnyj sajt «Trest Zhylstroj-1» [Official site of Trust «Zhilstroy-1»]. Retrieved from: http://gs1.com.ua/page/about (accessed 19 March 2020).

\section{THE EFFECT OF STOCK EXCHANGE TRADING MECHANISM ON MARKET EFFICIENCY}

\section{Vitalii Ihnatiuk ${ }^{1}$}

DOI: https://doi.org/10.30525/978-9934-588-39-6-47

Financial equity market is an efficient mechanism of information aggregation and price discovery. However, due to the specifics of modern equity exchange implementations, a market participant has to maintain an open order to display his demand/supply. The less the market price deviates from the equilibrium price, the less incentive one has to display it. Combined, this adds a time dimension to market equilibrium and challenges the notion of market efficiency.

By examining the recent findings in the field of metaorder trading and market infrastructure, we can prove that although this effect impairs market

\footnotetext{
${ }^{1}$ Taras Shevchenko National University of Kyiv, Ukraine
} 